\title{
Profile Characteristics and Analysis of the Constraints Faced by the Dairy Farmers of Urban and Peri-Urban Areas of Indian National Capital Region vis-a-vis Using Mobile Android Application "Eco-Dairy"
}

\author{
Shrija Sinha ${ }^{1^{*}}$, Gopal Sankhala ${ }^{1}$ and Sudhanand Prasad Lal ${ }^{2}$ \\ ${ }^{1}$ Dairy Extension Division, ICAR-National Dairy Research Institute, Karnal, Haryana, India \\ ${ }^{2}$ Division of Agricultural Extension, ICAR-Indian Agricultural Research Institute, \\ New Delhi, India \\ *Corresponding author
}

\section{A B S T R A C T}

\section{Keywords}

Constraints, Profile characteristics,

Cumulative square root frequency, Garret ranking

Article Info

Accepted:

20 February 2018

Available Online:

10 March 2018
Of the recent advancements in ICT and its application in agriculture and allied sector; mobile apps have the potential to convert world into a digital ecosystem. Reckoning with this fact a new mobile application called "Eco-Dairy" was developed to disseminate information on Environment Friendly Dairy Farming Practices (EFDFPs). This paper uncovers the constraints faced by the respondents in using the developed android application as well as throws a light on the profile variables of the respondents. Statistics like cumulative square root frequency and garret ranking method was used for analysing the data. Basically respondents were falling under middle age group $(56.67 \%)$, mostly male $(88.67 \%)$, functionally literate $(35.33 \%)$, were in low income group $(62.00 \%)$, had marginal land holding $(67.33 \%)$ and 82 per cent of them possessed smart phones. Of the constraints perceived by the respondents 'Difficulty in reading the screen text', 'Lack of skill in operating the smart phone' and 'Non availability of time' were the main constraints while using the application and were ranked I, II and III respectively.

\section{Introduction}

The past decade application of new and mod information and communication technologies for the development of rural India has grown expeditiously and is expected to transform the information delivery system from routine paper mode to a highly interactive and quick online mode. With this advancement in instrumentality for transferring the technology to the end user's i.e. farmers, a new channel has emerged out of basket; this is 'Mobile Agricultural Apps'. Costopoulou et al., (2016) defined the term Mobile Agricultural Apps as mobile applications which target the needs of the agricultural sector and its stakeholders, such as farmers, input dealers, cooperation etc. Reckoning with this fact a new mobile application called "Eco-Dairy" was developed to disseminate information on Environment Friendly Dairy Farming Practices (EFDFPs). EFDFPs are the combination of different adaptive and mitigating strategies to combat the ill effects of livestock on environment and vice-versa. 
Constraints analysis is very prevalent in survey-based research as Lal et al., (2016b) through exploratory factor analysis (EFA) explored 4 latent broad constraints having Eigen value $>1$, which was rechristened as: environmental, pecuniary, policy and miscellaneous constraints. Moreover, responses of the dairy farmers on extent of severity of constraints faced after national calamity was expounded by Lal et al., (2016a) by using Friedman test and it statistically identified that the most severe broad constraints perceived by dairy farmers was 'technical constraints' followed by 'economical constraints', 'physical constraints', and 'social constraints'.

In similar line this paper uncovers the constraints faced by the respondents which in this case were dairy farmers of urban and periurban areas of Indian National Capital Region; in using the developed android application. Along with this, the article unveils the profile characteristics of the respondents which give an unambiguous picture of respondents' background, living condition, surrounding and belongings to the researchers; further helping them draw suitable implications of the results.

\section{Materials and Methods}

\section{Locale of study and sampling plan}

Urban and Peri-Urban area of the Indian National Capital Region (NCR) was chosen as the study area. The National Capital Region (NCR) of India includes a whole of 33 districts of four states namely NCT of Delhi, Haryana, Uttar Pradesh and Rajasthan.

Out of which six districts i.e. namely North Delhi, North West Delhi, Sonipat, Panipat, Bagpat and Alwar were selected by using proportionate stratified random sampling technique subject to condition that there must be at least one district from each state.
Twenty-Five respondents from each of the selected cities of the four states were selected randomly. Pooling which; made a set of total 150 respondents. These 150 respondents were interviewed to get primary information on the topic with the help of semi structured interview schedule and open discussion method.

\section{Statistical tools and techniques for analysing the collected data}

To convert the obtained data into meaningful findings, the statistical tools used were Frequency, Percentage, Cumulative Square Root Frequency and Garret ranking.

\section{Statistics used for determining profile characteristics of respondents}

The primary data collected by the respondent in the context of their profile variables were tabulated and analysed by following statistical tools.

\section{Percentage}

For making sample comparisons, the percentage value was devised by dividing the frequency of a particular cell by total number of respondents in a particular category and multiplying it by 100 (Vairagar et al., 2015).

\section{$\mathrm{P}=\frac{\boldsymbol{n}}{\boldsymbol{N}} \times 100$}

Where,

$\mathrm{n}=$ frequency of a particular cell

$\mathrm{N}=$ Total number of respondents

$\mathrm{P}=$ Percentage

\section{Frequency}

It was calculated to find out the number of respondents in a particular cell. 


\section{Cumulative square root frequency}

For determining stratum boundaries, cumulative square root of frequency (CSRF) method was used. This method allows greater efficiency for setting stratum boundaries. CSRF methodology breaks down the population into intervals, which can be of equal or unequal width. The steps involved in its calculation are described below:

Evaluate the data and determine the units that can be reviewed on an actual basis.

Stratify the remaining data into ranges or classes. Number of classes and class interval are determined using the following formulas:

No. of classes $=2.5 \times$ (number of samples) $1 / 4$

$$
\text { (Largest figure - smallest figure) }
$$

Class interval $=$

No. of classes

Determine the frequency for each range. This is the number of units within the range.

Calculate the square root of the frequency for the first range. Then calculate the square root of the next range. Continue this process for each of the ranges.

Sum of the square root of the first and second range gives cumulative square root of the second range; sum of first, second and third gives the third range and so on for all the ranges.

The cumulative square root frequency value of the last class is divided by the number of sample strata desired (can vary 3-9) to get the cumulative square root value for each item.

Suppose, we desire to have 3 strata, then the upper limit of the first strata is determined using the formula as given below:
$\mathrm{Li}=\mathrm{Yi}-1+\frac{(\mathrm{Yi}-\mathrm{Yi}-1)}{-----}\{(\mathrm{Sk} / \mathrm{L})-\mathrm{Si}-1\}$ Value 1

Where,

$\mathrm{Li}=$ Upper limit of the $\mathrm{i}^{\text {th }}$ strata (In this case first strata)

$\mathrm{L}=$ Number of strata

$\mathrm{Yi}=$ Upper limit of the class in which Li lies

Yi-1 = Lower limit of the class in which $\mathrm{Li}$ lies

$\mathrm{Sk}=$ Cumulative square root frequency value

$\sqrt{ } \mathrm{f}=$ Square root of the frequency of the $\mathrm{i}^{\text {th }}$ class in which $\mathrm{Li}(\mathrm{Sk} / \mathrm{L})$ lies

$\mathrm{Si}-1$ = Cumulative square root frequency of the preceding class in which $\mathrm{Li}(\mathrm{Sk} / \mathrm{L})$ lies

Yi - Yi-1= Width of the class in which in which $\mathrm{Li}(\mathrm{Sk} / \mathrm{L})$ lies

For the upper limit of second strata, the formula is:

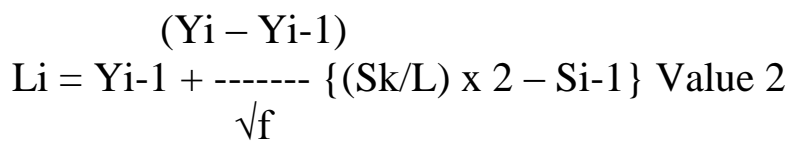

For the upper limit of third strata, the formula is:

$\mathrm{Li}=\mathrm{Yi}-1+\underset{ل_{\mathrm{f}}}{(\mathrm{Yi}-\mathrm{Yi}-1)}\{(\mathrm{Sk} / \mathrm{L}) \times 3-\mathrm{Si}-1\}$ Value 3

In this way, three strata are formed i.e., below value 1 , between (value 1 and value 2) and above (value 2 up to value 3). Out of the nine profile variable for determining three variables namely: family size, annual income, 
experiences in dairying this statistics was used.

\section{Statistics used for determining appropriate rank of the constraints}

The interview schedule developed for the study included a section with a set of all possible constraints which a dairy farmers could face while using the mobile app "EcoDairy".

These were ranked by the respondents according to their objective views.

Later data was tabulated and analysed using the method of combining incomplete order of merit ranking called Garret Ranking Method (Garret and Woodworth, 1969).

Following this method, ranks given by the respondents was converted into score value with the help of the following formula:

Percent position $=\frac{100(\mathrm{Rij}-0.5)}{\mathrm{Nj}}$

Where,

$\mathrm{Rij}=$ Rank given for the $\mathrm{i}^{\text {th }}$ variable by $\mathrm{j}^{\text {th }}$ respondents

$\mathrm{Nj}=$ Number of variable ranked by $\mathrm{j}^{\text {th }}$ respondents

With the help of Garrett's Table, the percent position estimated was converted into scores.

Then for each factor, the scores of each individual were added and then total value of scores and mean values of score was calculated.

The factors having highest mean value is considered to be the most important factor.

\section{Results and Discussion}

\section{Profile characteristics of the respondents}

Profiling of the respondents from six districts of NCR region was carried out to get a clearcut understanding about the respondents and their perception towards the mobile app (Eco dairy). In the present study nine profile variables were taken into consideration. A bird's eye view of the Table 1 reveals that majority $(56.67 \%)$ of the respondents in the study area belonged to middle age group (3650years), this could be because youth today are not willing enough to take up agriculture and allied sectors as their career, instead migrate to big cities in search of better employment opportunities. Talking about old aged people, they generally avoid taking up agriculture and allied sectors, because it requires a lot of physical strength, which they lack.

It was established, that 88.67 per cent of the respondents were male whereas only 11.33 per cent respondents were female. It could be due to fact that males take lead in the ownership of dairy as ours happen to be a patriarchal society. In almost all the families the descendants are male and ownership is transferred to women only when there is no male member to lead the family. The third profile variable was 'Education', it was found that majority of the respondents were functionally literate $(35.33 \%)$ followed by respondents having primary education (25.33\%), illiterate $(17.33 \%)$, Middle education $(7.33 \%)$,secondary education (4.67 $\%)$, Higher Secondary education $(6.00 \%)$ and college and above $(4.00 \%)$. This could be due to the improved communication services available in the urban and peri urban areas i.e. mainly multimedia exposure, awareness among the people regarding importance of education etc, that these dairy farmers can read and write in spite of lacking a matriculation degree. 
Table.1 Profile Variables of the respondents

\begin{tabular}{|c|c|c|c|}
\hline SI. No. & Category & \multicolumn{2}{|c|}{ Respondents $(\mathrm{n}=150)$} \\
\hline 1 & Age in years & Frequency & Percentage \\
\hline 1 & Young(upto 35) & 32 & 21.33 \\
\hline 2 & Middle-aged(36-50) & 85 & 56.67 \\
\hline \multirow[t]{2}{*}{3} & $\operatorname{Old}(>50)$ & 33 & 22.00 \\
\hline & Total & 150 & 100 \\
\hline B. & Gender & Frequency & Percentage \\
\hline 1 & Male & 133 & 88.67 \\
\hline \multirow[t]{2}{*}{2} & Female & 17 & 11.33 \\
\hline & Total & 150 & 100 \\
\hline C. & Education & Frequency & Percentage \\
\hline 1 & Illiterate & 26 & 17.33 \\
\hline 2 & Functionally literate & 53 & 35.34 \\
\hline 3 & Primary Education & 38 & 25.33 \\
\hline 4 & Middle Education & 11 & 7.33 \\
\hline 5 & Secondary Education & 7 & 4.67 \\
\hline 6 & Higher Secondary Education & 9 & 6.00 \\
\hline \multirow[t]{2}{*}{7} & College and above & 6 & 4.00 \\
\hline & Total & 150 & 100 \\
\hline D. & Family Type & Frequency & Percentage \\
\hline 1 & Nuclear family & 87 & 58.00 \\
\hline \multirow[t]{2}{*}{2} & Joint Family & 63 & 42.00 \\
\hline & Total & 150 & 100 \\
\hline E. & Family Size & Frequency & Percentage \\
\hline 1 & $<5$ Members & 27 & 18.00 \\
\hline 2 & $5-7$ Members & 110 & 73.33 \\
\hline \multirow[t]{2}{*}{3} & $>7$ Members & 13 & 8.67 \\
\hline & Total & 150 & 100 \\
\hline F. & Annual Income & Frequency & Percentage \\
\hline 1. & Low $(<2.39$ lakhs $)$ & 93 & 62.00 \\
\hline 2. & Medium (2.39-3.78 lakhs) & 34 & 22.67 \\
\hline \multirow[t]{2}{*}{3.} & High (>3.78 lakhs) & 23 & 15.33 \\
\hline & Total & 150 & 100 \\
\hline G. & Land Holding & Frequency & Percentage \\
\hline 1 & Marginal Farmers (up to 2.5 acres) & 101 & 67.33 \\
\hline 2 & Small Farmers (2.51 to 5.00 acres) & 27 & 18.00 \\
\hline 3 & Medium Farmers (5.00 to 10.00 acres) & 16 & 10.67 \\
\hline \multirow[t]{2}{*}{4} & Large Farmers (Above 10.00 acres) & 6 & 4.00 \\
\hline & Total & 150 & 100 \\
\hline H. & Experience in Dairying & Frequency & Percentage \\
\hline 1. & Low $(<12.36$ years $)$ & 7 & 4.67 \\
\hline 2. & Middle (12.36- 19.42 years) & 37 & 24.67 \\
\hline \multirow[t]{2}{*}{3.} & High $(>19.42$ years $)$ & 106 & 70.66 \\
\hline & Total & 150 & 100 \\
\hline
\end{tabular}


Table.2 Constraints perceived by the respondents in using the ICT gadgets

\begin{tabular}{|c|l|c|c|}
\hline S. No & \multicolumn{1}{|c|}{ Constraints } & $\begin{array}{c}\text { Garret } \\
\text { Mean Score }\end{array}$ & Rank \\
\hline 1. & Difficulty in reading the screen text & 71.68 & 1 \\
\hline 2. & Lack of skill in operating the smart phone & 68.76 & 2 \\
\hline 3 & Non availability of time & 58.80 & 3 \\
\hline 4. & Hiked internet cost & 52.01 & 4 \\
\hline 5. & Lack of interest among the respondents & 41.23 & 5 \\
\hline 6. & Difficulty in understanding the language of App & 31.20 & 6 \\
\hline 7 & $\begin{array}{l}\text { Lack of availability of the smart phone among the } \\
\text { respondents }\end{array}$ & 27.32 & 7 \\
\hline
\end{tabular}

Graph.1 ICT Tool Availability among the Respondents

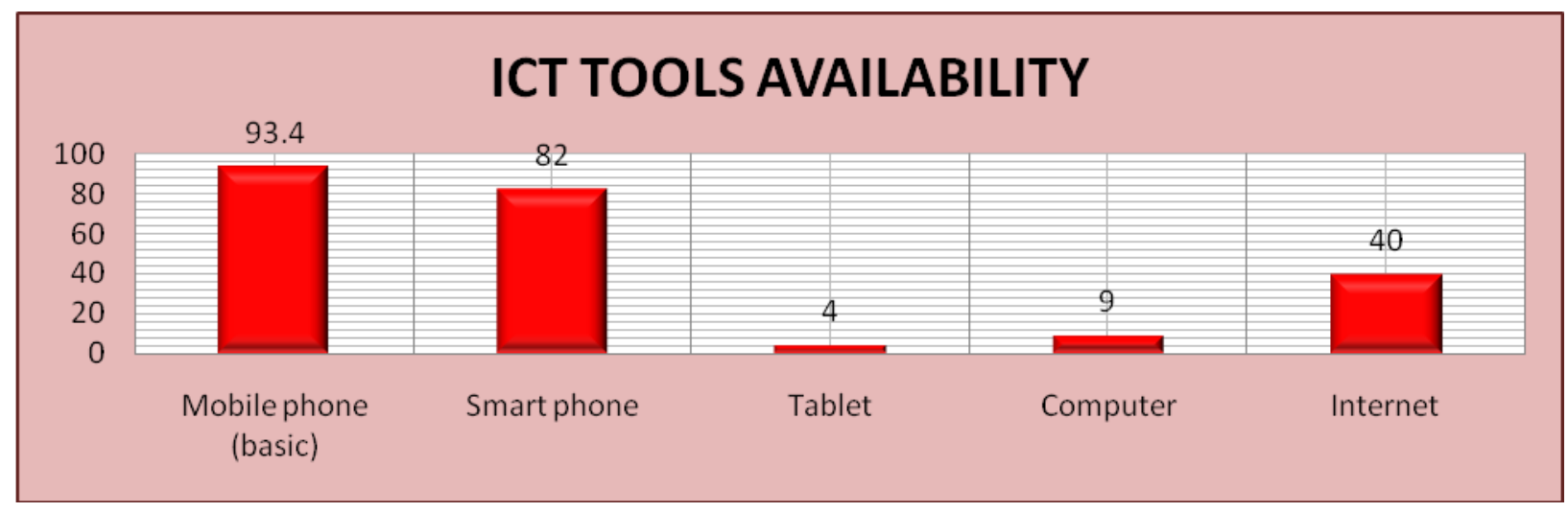

Inevitable necessity in the family, lack of interest, financial problems could be the major reasons behind the low literacy level among the respondents.

Table 1 even show, that a large number of the respondents $(58.00 \%)$ had nuclear family, however only 42.00 per cent of the respondents had joint family. The probable reason behind this could be the fact that some of the respondents migrated from their villages after separating from the joint family and eventually settled in the urban areas. Urban influence could be another main reason behind this trend. 73.33 per cent of the respondents had medium sized family. It might be because of the fact people now-adays are increasingly getting aware about the issues of growing population like high expenditures required for maintaining optimum level of living as well as for fulfilling basic needs like good education for children etc.

Sixty two per cent of the respondents were falling under the low annual income group. While as many as sixty-seven per cent of the respondents had marginalized land holding. Talking about the eight variable 'experience in dairying' it could be seen from the table 1 that majority of the respondents i.e. 70.66 per cent have high level of experience in dairying, this could be because dairying is an age long practice, which is being carried out by the respondents and their fore fathers. 
Finally the last variable was 'ICT Tool availability among the respondents'(Graph 1); it was found that 82 per cent respondents possessed smart phone and about 40 per cent of them were having access to internet facilities in their mobile phone/tablets/ computers. The probable reason behind this could be easy availability of smart phone, low price of smart phone etc.

\section{Constraints Perceived by the Respondents While Using the Mobile Application. (Eco dairy)}

The data presented in the Table. 2 revealed that, 'Difficulty in reading the screen text' happens to be the major constraint as perceived by the respondents, and it was ranked first with a garret mean score of 71.68. This constraint hinders the respondents interest in using the application for the purpose of fetching the information regarding the topic. It could be because of cyber illiteracy, most of the people in spite of keeping the smart phone are not interested in learning the features in it. 'Lack of skill in operating the smart phone' was found to be the second most important constraints perceived by respondents with a garret mean score of 68.76. In spite of having access to smart phones, the main reason behind this constraint could be lack of understanding of the functions of the application.

'Non availability of time' (Garret mean score $=58.80)$ was reported to be the third most important constraint as perceived by the respondents. Reason for this could be prior engagement of the respondents in their multi facet work both at farm and home.

'Hiked internet cost' (Garret mean score= 52.01) was the fourth major constraint of the respondents. It could be because most of the people in spite of advent of new internet plans at low cost were not keeping the smart phone which supports those sim cards or are either unaware of such facilities and plans.

'Lack of interest among the respondents' (Garret mean score $=41.23$ ) was another major constraint which hindered the usage of the application among the respondents. This problem was ranked fifth. The possible reason behind this could be negligence of the farmer, lack of intrinsic motivation etc.

'Difficulty in understanding the language' of the application (Garret mean Score $=31.20$ ) was ranked sixth in the list. This might be due to lack of education facility of the respondents in study area. 'Lack of availability of the smart phone among the respondents' was having a garret mean score of 27.32 and ranked seventh on the list. This could be because of the fact that majority of respondents' possessed smart phones.

From the above study is can be concluded that the respondents were falling under middle age group $(56.67 \%)$, mostly male (88.67 \%), functionally literate $(35.33 \%)$, were in low income group $(62.00 \%)$, had marginal land holding $(67.33 \%)$ and 82 per cent possessed smart phones. Of the constraints perceived by the respondents 'Difficulty in reading the screen text', 'Lack of skill in operating the smart phone' and 'Non availability of time' were the main constraints while using the application and were ranked I, II and III, respectively.

Of the recent advancements in ICT and its application in agriculture and allied sector; mobile apps have the potential to convert world into a digital ecosystem. Though in developing counties like India, this innovative attempt can witness a slow progress. Efforts Should made to accelerate its impact for rural development in line with world banks guideline (2012).According to world bank benefits of the mobile based application in agriculture can be achieved by making 
provision of better access of information and agricultural extension services.

\section{References}

Costopoulou, C., Ntaliani, $\mathrm{M}$ and Karetsos, S., 2016. Studying Mobile Apps for Agriculture. Journal of Mobile Computing and Application, 3(6): 44-99

Garrett, H.E., Woodworth, R.S., 1969. Statistics in Psychology and Education. Vakils, Feffer and Simons Pvt. Ltd., Bombay, India, p. 329.

Lal, S.P., Kadian, K.S., Kale, R. B. and Shruti, 2016a. Friedman based analysis of perceived constraints among dairy farmers affected by national calamity in India. Indian J Dairy Sci., 69(6): 725727.
Lal, S.P., Kadian, K.S., Wodajo, W.A. and Shruti, 2016b. Is that environmental factor affected the distressed farmers' most?! - An Exploratory factor analysis of constraint and amelioration strategies in national calamity hit region of India. Current World Environment, 11(3):859868.

Vairagar, V. G., Sankhala, G., Kale, R. B. and $\mathrm{Kad}$, S. V. 2015. Preferences of Stakeholders towards health foods. International Journal of Tropical Agriculture, 33 (2): 1495- 1499.

World Bank, 2012. Mobile applications for agriculture and rural development. Washington, D.C.: World Bank Group. URL: http://documents.worldbank.org/ curated/en/167301467999716265/Mobil e-applications-for-agriculture-and-ruraldevelopment/

\section{How to cite this article:}

Shrija Sinha, Gopal Sankhala and Sudhanand Prasad Lal. 2018. Profile Characteristics and Analysis of the Constraints Faced by the Dairy Farmers of Urban and Peri-Urban Areas of Indian National Capital Region vis-a-vis Using Mobile Android Application "Eco-Dairy". Int.J.Curr.Microbiol.App.Sci. 7(03): 2335-2342. doi: https://doi.org/10.20546/ijcmas.2018.703.274 